\title{
THE IMPACT OF THE TERRITORIAL MARKETING ON HIGHLIGHTING THE BRAND "BAIKAL" IN THE BAIKAL REGION
}

\author{
Valentina NAKONECHNYKH* \\ V.N. Nakonechnykh Irkutsk State University, Department of Advertising, \\ 126 Lermontov st., 664033, Irkutsk, Russia, e-mail: nvn_60@mail.ru

\section{Margarita ZHURAVLEVA} \\ M.M. Zhuravleva Irkutsk State University, Department of Tourism, \\ 126 Lermontov st., 664033, Irkutsk, Russia, e-mail: margo32@mail.ru
}

\section{Anastasiia SIVKOVA}

A.V. Sivkova Irkutsk State University, Department of Advertising, 126 Lermontov st., 664033, Irkutsk, Russia, e-mail: sivkova@yandex.ru

\section{Svetlana VOLOKHOVA}

S.G. Volokhova Irkutsk State University, Department of Entrepreneurship and Management in Services and Advertising, 126 Lermontov st., 664033, Irkutsk, Russia, e-mail: sve-volokhova@ya.ru

\begin{abstract}
Citation: Nakonechnykh, V., Zhuravleva, M., Sivkova, A. \& Volokhova, S. (2019). THE IMPACT OF THE TERRITORIAL MARKETING ON HIGHLIGHTING THE BRAND «BAIKAL» IN THE BAIKAL REGION. GeoJournal of Tourism and Geosites, 27(4), 1271-1279. https://doi.org/10.30892/gtg.27413-432
\end{abstract}

\begin{abstract}
The formation of the global market for geoproducts in the Baikal region causes a growing interest in the study of the phenomenon of "Brand of the territory", which affects the effectiveness of the promotion of the territory in the face of growing competition. An analysis of the current state of tourism in many countries makes it clear that tourism development should be accompanied by efforts to promote domestic tourism programs. The purpose of this article is to analyze and to identify tools to attract attention and develop guidelines for the formation of the brand of Baikal and the Irkutsk region as a whole. In the development of the attractiveness of the territory for its potential consumers, the "Territory Brand" plays an important role. It is he who adds value to the geoproduct. Tools for determining the cost of a geoproduct are a marketing analysis of territories - a SWOT analysis of a territory (analysis of strengths, weaknesses, opportunities and threats), analysis and selection of target markets, and positioning (determination of current and desired positions) of territories. The Baikal region is a unique regional ecosystem, which is the most actively developing and becoming a kind of zone of attraction and pilgrimage not only for scientists, but also for many recreants and vacationers. The Baikal region must necessarily have its own identity, name and slogan, which would make it possible to attract as much money into the budget of the territory and give residents a reason for pride
\end{abstract}

\footnotetext{
* Corresponding author
} 
and self-identification. The brand name is determined by the name of the Baikal territory. The marketing strategy of attractiveness as the optimal strategy for the development of the region was determined, since its prerequisites were originally set by the history and favorable geographical position of Lake Baikal.It is important to develop a platform for the brand of the territory and to develop a creative brand concept in the process of branding the Baikal territory.

Key words: territorial marketing, brand, geoproduct, development, global market, domestic tourism programs.

\section{INTRODUCTION}

The relevance of the study is explained by the fact that the reputation of the territory becomes a part of national capital and is interpreted from the position of determining the strategic priorities of the development of the country (region) and the national idea. The formation of the global market for geoproducts determines the interest in the study of the phenomenon of "brand territory", which affects the effectiveness of the promotion of the territory in the face of growing competition. And this, in turn, affects the development of tourism. The urgency of the problem is obvious and is due to the fact that the Irkutsk region has huge tourism potential: the unique natural resources of Lake Baikal, its rich historical and cultural heritage. All this forms the brand of Baikal and contributes to the attractiveness of the region as a tourist destination.The purpose of this article is to analyze and to identify tools to attract attention and develop guidelines for the formation of the brand of Baikal and the Irkutsk region as a whole.

\section{THE RESEARCH TERRITORY}

Lake Baikal is located in the center of the Asian continent, on the border of two constituent entities of the Russian Federation: Irkutsk Region and the Republic of Buryatia. The western part of Lake Baikal with the island of Olkhon is administratively part of the Irkutsk region, and the eastern part with the northern extremity belongs to the Republic of Buryatia, with borders on the west bank along the Elokhin Cape, on the southern - along the Snezhnaya River. In general, about $60 \%$ of the Baikal coast is located in Buryatia, 40\% - in the Irkutsk region (Suprun, 2006). The lake lies in a sort of basin, surrounded by high mountain ridges and high hills on all sides.

The western shore of Lake Baikal is rocky and steep, while the terrain of the eastern shore is flatter. The area of Lake Baikal is a territory of very high seismic activity: earthquakes happen at the all the time, but most of them are left unnoticed their magnitude only amounts to one or two points on Richter scale (Galazy, 2019). The main significant characteristics of the Baikal territory are usually (Galazy, 1987):

- Baikal is 20-25 million years old.

- Baikal is a unique creation of the nature with crystal clear and very clean water (Figure 1).

- It is the oldest existing freshwater lake on Earth (20 million-25 million years old), as well as the deepest continental body of water, having a maximum depth of 5,315 feet $(1,620$ metres). Its area is some 12,200 square miles $(31,500$ square $\mathrm{km})$, with a length of 395 miles $(636 \mathrm{~km})$ and an average width of 30 miles $(48 \mathrm{~km})$. It is also the world's largest freshwater lake by volume, containing about one-fifth of the fresh water on Earth's surface, some 5,500 cubic miles (23,000 cubic km). 
- Into Lake Baikal flow more than 330 rivers and streams, the largest of which include the Selenga, Barguzin, Upper (Verkhnyaya) Angara, Chikoy, and Uda. There are 30 islands in the territory of Baikal. The largest of them is the island of Olkhon, which is called the pearl of Lake Baikal.

- The Limnological Institute of the Siberian Division of the Russian Academy of Sciences is located in the town of Listvyanka, as is the Baikal Sanatorium, and the hydrobiological station of Irkutsk State University is in Bolshiye Koty (Bolshoy Koti).

- In December 1996, Lake Baikal was included in the UNESCO World Heritage List.

- Baikal's climate is much milder than that of the surrounding territory. Winter air temperatures average $-6^{\circ} \mathrm{F}\left(-21^{\circ} \mathrm{C}\right)$, and August temperatures average $5^{\circ}{ }^{\circ} \mathrm{F}(11$ ${ }^{\circ} \mathrm{C}$ ). The lake surface freezes in January and thaws in May or June. The water temperature at the surface in August is between 50 and $54{ }^{\circ} \mathrm{F}\left(10\right.$ and $12{ }^{\circ} \mathrm{C}$ ) and reaches $68{ }^{\circ} \mathrm{F}\left(20^{\circ} \mathrm{C}\right)$ in the offshore shallows.

- Plant and animal life in the lake is rich and various. There are between 1,500 and 1,800 animal species at different depths, and hundreds of plant species live on or near the surface.

- There are more than 320 bird species in the Baikal area.

- Baikal contains some 45 islets and islands, the largest of which are Olkhon (about 270 square miles [700 square km]) and Bolshoy (Great) Ushkany (3.6 square miles [9.4 square $\mathrm{km}])$ (Galazy, 1987).

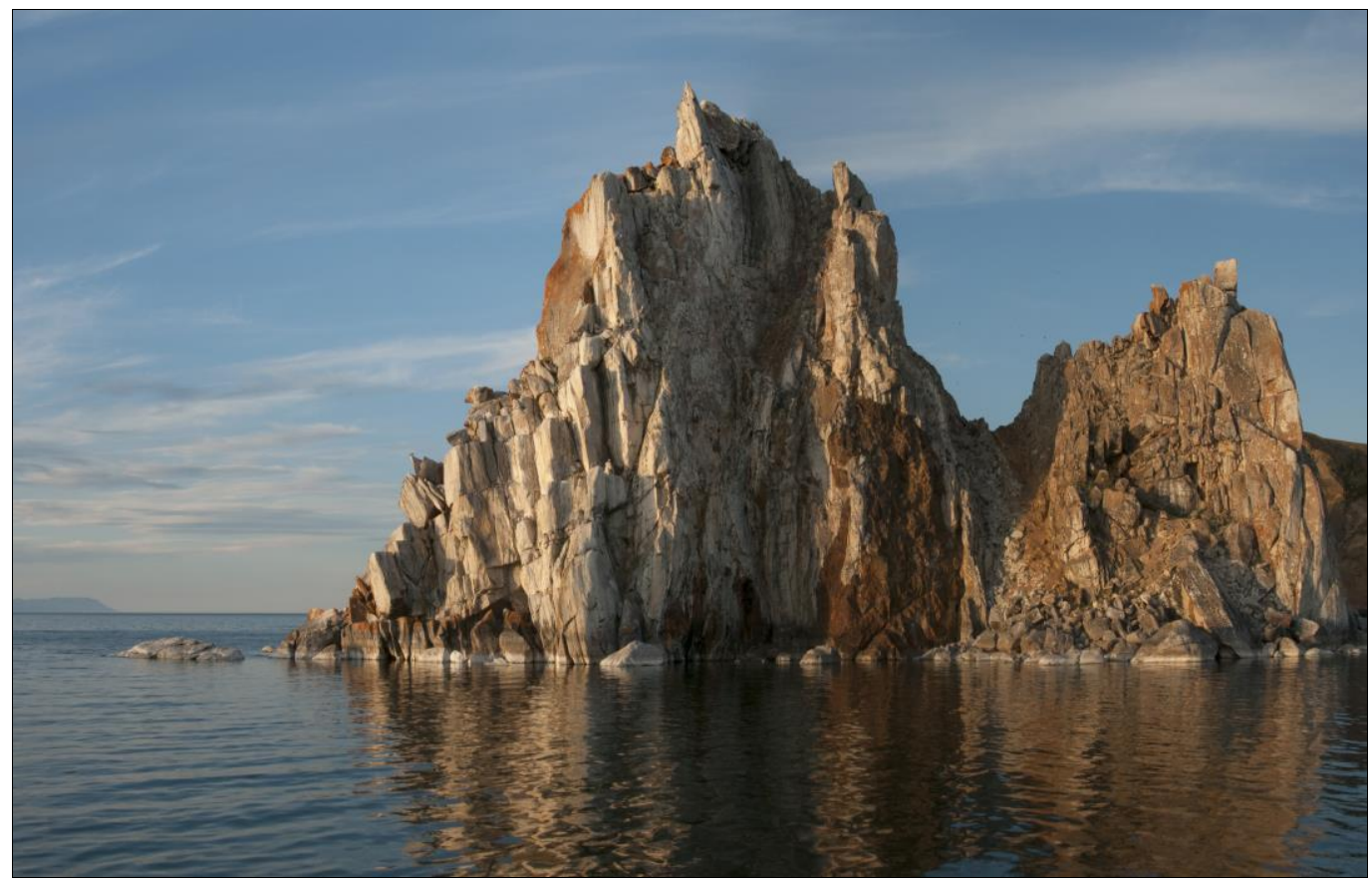

Figure 1. Lake Baikal

Currently, the development and solution of problems of branding territories is becoming relevant. The latter is reflected in the organization of scientific conferences, seminars, in the decisions of municipal governments to pursue a policy of creating a positive brand of territorial objects. In this area, works on the reputation management 
of territories “Territory Marketing”, “Counter-marketing. Debranding and destruction of the image of the territory according to the image of the regions" (Pankhrukhin, 2008), "Image and reputation of the territory as the basis for promotion in a competitive environment" (Vazhenina, 2008) and other scientists (Kavaratzis, 2004).

Branding activity has been the subject of analysis by many foreign experts (Kotler et al., 2010, Lucarelli \& Berg, 2011, Sevin, 2014) in the field of market research and consumer behavior: "Brand forever: creation, development, support of brand value", "America: mother of all brands" (Anholt, 2005, 2007, 2010; Gozner et al., 2017; Ilieș et al., 2018; Lincu et al., 2018; Tătar et al., 2018). At the same time, the theoretical, methodological and practical problems of branding the tourist territories and their promotion have not been sufficiently developed (Baker \& Cameron, 2008).

An important role in this is given to territorial marketing (Kotleret et al., 1999; Niedomysl, 2012; Szondi, 2007). The concept of territorial marketing was considered as a process of planning, coordinating and controlling the direct ties of territorial administration with its various partners and target groups (Funke, 1998; Kotler et et al., 2002). Territorial marketing is marketing in the interests of the territory, its internal entities, as well as external entities, in which the territory is interested"(Lyubashevsky, 2005; Pankhrukhin, 2008; Kotler et al., 2010).

\section{MATERIALS AND METHODS}

In the development of the attractiveness of the territory for its potential consumers, the "Territory Brand" plays an important role. It is he who adds value to the geoproduct.

Tools for determining the cost of a geoproduct are a marketing analysis of territories - a SWOT analysis of a territory (analysis of strengths, weaknesses, opportunities and threats), analysis and selection of target markets, and positioning (determination of current and desired positions) of territories (Gozner et al., 2016; Ilieș et al., 2018; Indrie et al., 2018; Komarov, 2005; Dumova, 2010). According to the SWOT analysis the strengths, weaknesses, opportunities and threats of the Baikal region have been described in this article:

Strengths:

1. Geopolitical position: the Trans-Siberian Railway passes through the region, which plays a key role in the delivery of products from the Far East and the Baikal region to Russian markets and markets in the Asia-Pacific region.

2. According to economic traditions, more than $3 / 4$ of all mutual deliveries of products and goods between the Baikal region and the regions of Russia fall to the Siberian Federal District - 68.4\%.

The economic and geographical location is advantageous, since the Baikal region is a link between the East and West of Russia.

3. Natural and climatic potential:

- The basis for the initial positioning consists of the so-called renewable resources. From the point of view of using raw materials, it is precisely the sectors related to renewable resources that have the greatest potential in promoting the region to foreign markets - the forestry and agro-industrial complex, including all sectors of crop production, livestock raising, production and processing of land and forest products.

- The richness of nature and a wide variety of flora and fauna in the region.

- Climatic conditions and natural resources are combined in such a way that allows you to engage in different types of tourism.

4. The territory of cultural heritage.

The region is characterized by rich cultural heritage. Important cultural attractions 
of the region are archaeological finds of ancient cultures on the shores of Lake Baikal, the traditional architecture of the settlements around the lake, 19th century buildings.

5. Economic structure:

- In the economy, the most promising and dynamically developing are: electric power, fuel industry, mechanical engineering and metalworking, non-ferrous metallurgy, timber, woodworking and pulp and paper industries, food and light industries.

- A sufficiently developed level of infrastructure, especially transport. The airport in Irkutsk, as well as the presence of the Trans-Siberian Railway confirm the sufficiency of the transport system to serve domestic and international tourism.

6. Foreign trade turnover and foreign investment:

According to expert estimates, the Baikal region is among the twenty regions with the highest resource potential, and the top five regions with a favorable legislative background for foreign investment.

- The capital of 29 countries is involved in the creation of enterprises with foreign investment in the region, with most of the FDI (136) formed with the participation of countries in the Asia-Pacific region. The largest number of joint ventures was created with China (62), Mongolia (26) and the Republic of Korea (9) (Sanaev, 2011).

At the same time, the region has its weaknesses that impede its further development. These weaknesses can be characterized as follows:

Geopolitical position:

- Today the region is cut off from the nearest traditional markets by its neighbors: from the west, the promotion of goods is blocked by the growing internal integration of the subjects of the Ural Federal District, as well as by such neighbors as the Krasnoyarsk Territory, as well as by the powerful agricultural potential of the Altai Territory; barriers from the east are formed by the Amur Region, the Khabarovsk and Primorsky Territories, which have a much similar economy in structure and have the advantage of access to the sea routes. Thus, the expansion of goods in these areas is accompanied by fierce competition.

- High transport tariffs, which amount to $33 \%$ of the country's cargo turnover, are almost twice as much as the share of gross domestic product (Sanaev, 2011). Accordingly, the tariff burden per unit of output is twice as high.

Therefore, current tariffs literally tear apart the economic space, physically tearing the east from the west of the country. It must be admitted that the strict policy of the maximum possible withdrawal of the resources of Siberia and the Far East at some point made it possible to save the country's economy from complete collapse, but at the same time it undermined the economic forces of the eastern regions.

7. Natural and climatic potential:

- Geological exploration of the subsoil of the territory is insufficient.

- The risky farming zone does not fully provide the domestic market with agricultural products.

- An unfavorable factor is the environmental situation. The existence of two environmental monsters on the shores of Lake Baikal - the Baikal Pulp and Paper and the Selenga Pulp and Cardboard Mill. Their existence in pristine and picturesque places, and even more so their negative impact on the nature of Lake Baikal, puzzles many true connoisseurs of natural beauty.

Economic structure:

- The quality of product specialization remains unsatisfactory, primarily due to the lack of a system of regional brands and marketing support for the promotion of many products. 
- Inadequate development of the tourism sector. Poorly developed tourism infrastructure, poorly developed human resources. Lack of qualified personnel is one of the key parameters of this problem.

- Of particular difficulty is the lack of technology and know-how on the specifics of the marketing strategy and sales promotion schemes, as enterprises are not familiar with the new methods and tools used in management and marketing strategies.

Opportunities:

1. Russia and the new independent states as a whole have established good cooperation with European countries, especially EU member states. Through various tools for transferring know-how to sectors such as the development of the NSR or the restructuring of enterprises, there is a real opportunity to contribute to the economic development of the region.

2. In the context of global trends in globalization and regionalization, which have swept the whole world today. Globalization has become an objective process of our time and it is necessary to use the opportunities provided. That is why the uniqueness of Russia's geopolitical position lies in the fact that it adjoins the European Economic Space (EEC) and the Asia-Pacific region. The technological and human potential of the mega-region is huge, while the resources and spatial potential are limited. There is a situation that poses the Asia-Pacific region before a strategic choice of cooperation with rich Siberia.

Threats:

1. Price volatility in world raw materials markets, which forms the basis of the regional economy.

2. The threat to remain a raw materials appendage of the Center of Russia, if not to develop high-tech sectors of the economy (Blashenkova, 2012).

\section{RESULTS AND DISCUSSION}

The Baikal region is a unique regional ecosystem, which is the most actively developing and becoming a kind of zone of attraction and pilgrimage not only for scientists, but also for many recreants and vacationers. The uniqueness of Lake Baikal bases in the fact that there are many historical and cultural attractions represented by the sites of an ancient man with fortifications, caves, rocks, cliffs and memorials, or ancient letters and drawings. Currently, the tourism industry is developing steadily. According to the results of a study by the "Rating Information Center" and the magazine "Rest in Russia," the Irkutsk Region in 2018 retained the $13^{\text {the }}$ place in the rating of tourist attractiveness among Russian regions. Industry experts divided all 85 entities into three categories. The first ones that were selected were the most successful in 2017 and 2018. Ahead of the Angara region are such recognized tourist regions as the Krasnodar Territory, Moscow and the Moscow Region, the Republic of Crimea, and the Stavropol Territory. Among the subjects of the Siberian Federal District, which were in the top twenty, the Irkutsk region was ahead of only 2 Altai Territory.

To compile the rating, we used data for 2017 and January-September 2018 provided by the Federal State Statistics Service, the Ministry of Internal Affairs of the Russian Federation, information from the Unified State Register of Cultural Heritage Objects, as well as information on the number in the Yandex search engine with the keywords: " Rest in the + name of the region". Irkutsk region is included in the Golden League "Best of the Best" of the National Event Tourism Development Rating in Russia, compiled by the National Association of Event Tourism Specialists. In the ranking of Russian regions following the results of the National Event Tourism Award "Russian Event Awards" of 2018, the Irkutsk region took fifth place. When compiling the rating, 
the total number of projects from the region submitted for participation in the competition, the results of regional competitions, and the results of the final of the National Event Tourism Award "Russian Event Awards" were taken into account.

According to estimates by the Tourism Agency of the Irkutsk Region, the volume of services provided to tourists over the 9 months of 2018 increased by 11\%. Work continues on a regional tourism development strategy. Proposals were made to the passport of the priority project "Baikal: The Great Lake of the Great Country". In 2018, the Irkutsk region was included in the pilot project of the Federal Ministry of Culture to subsidize tour operators, which will positively affect the increase in organized tourist flow to the region. The basis of the tourist and recreational potential, of course, is Lake Baikal, included in the UNESCO World Heritage List (Interfax Tourism, 23.09.2019)

\section{CONCLUSION}

Naturally, the development of recreational resources and the revitalization of innovative activities on the shores of Lake Baikal lead to the stimulation of a civilized tourist industry and the formation of a tourism cluster, which are an integral part of the process of branding a tourist territory (Figure 2).

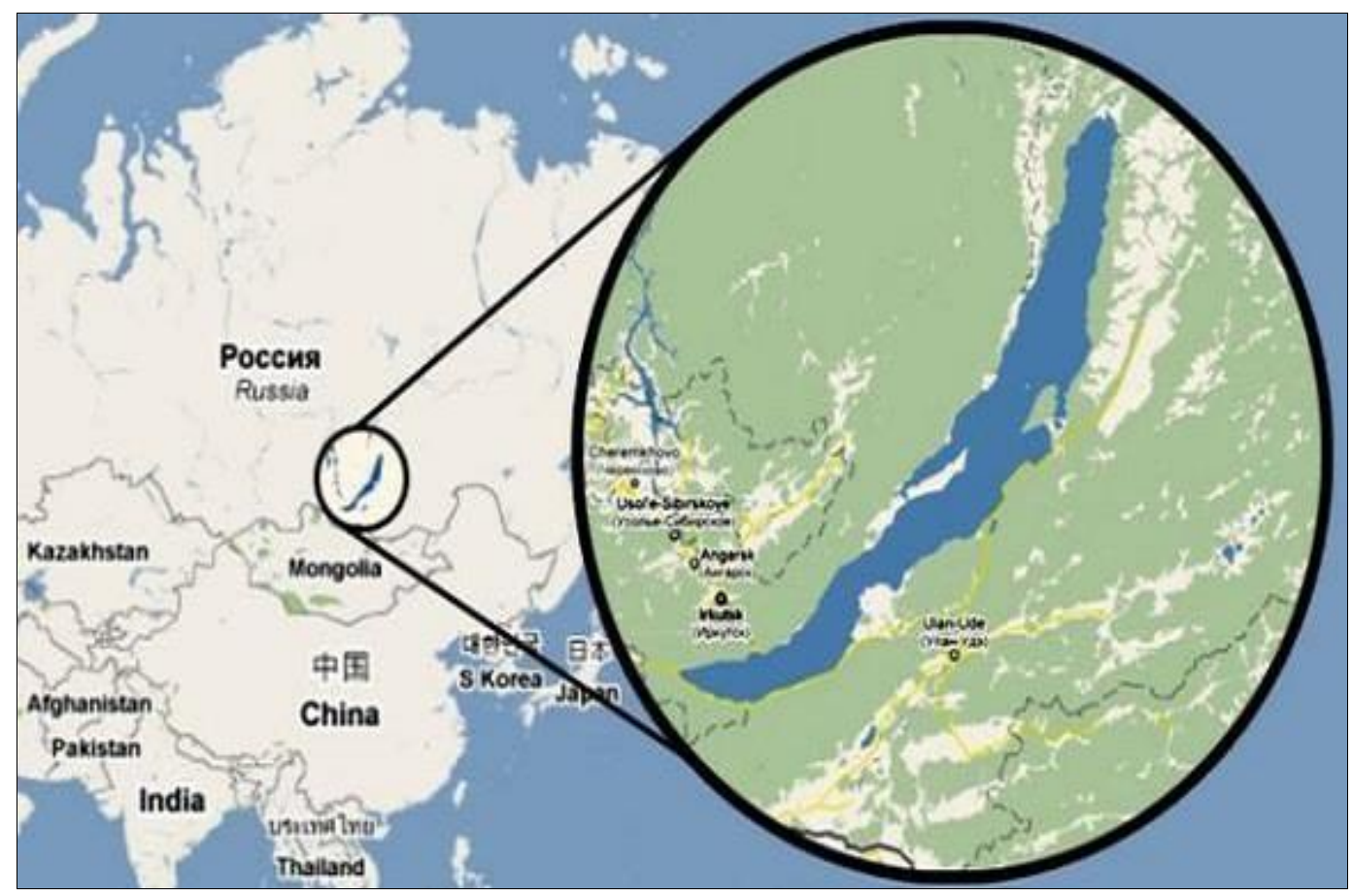

Figure 2. Map of Lake Baikal (www.beautifulworld.com/asia/russia/lake-baikal/, 2019)

The territorial brand plays an important role in developing the attractiveness of the territory for its potential consumers by creating additional consumer value, which creates additional economic value for the geoproduct.

We determined the marketing strategy of attractiveness as the optimal strategy for the development of the region, since its prerequisites were originally set by the history and favorable geographical position of Lake Baikal. In the process of branding 
the Baikal territory, we needed to develop a platform for the brand of the territory and develop a creative brand concept. During the development of the brand's platform, we described the vision, mission and values of the brand.

In our opinion, the region should be a global regional tourist complex with the idea of the need to preserve nature and act as its active defender, to promote the rational use of natural and cultural-historical tourist resources of Lake Baikal.

\section{Acknowledgement}

The authors would like to thank the Candidate of biological sciences, Assistant Professor of the Department of Tourism A.I. Tanichev for the made picture in this article.

\section{REFERENCES}

Anholt S. (2010). Definitions of place branding - Working towards a resolution, Place Branding and Public Diplomacy (6)1:1- 10 .

Anholt, S. (2005). Anholt Nation Brands Index: how does the world see America?”, Journal of Advertising Research, Vol. 45, No. 3, pp. 296- 304.

Anholt, S. (2007). Competitive Identity: The New Brand Management for Nations, Cities and Regions: Basingstoke, UK: Palgrave Macmillan, p. 25-26.

Anholt, S. (2013). Beyond the Nation Brand: The Role of Image and Identity in International Relations: the Journal of Public Diplomacy, Vol. 2, Iss. 1, Art. 1, p. 1-7.

Baker, M. \& Cameron, E. (2008). Critical success factors in destination marketing, Journal of Tourism and Hospitality Research, Vol. 8 No.2, pp. 79-97.

Blashenkova, V. (2012). How much does a brand of a territory (city, region, region) cost, from http://www. concretica.ru/publications/single/article/6/424, accessed 02.22.2012.

Briciu, V. (2013). Differences between Place. Branding and Destination. Branding for Local Brand. Strategy Development, Bulletin of the Transilvania University of Braşov, Series VII, Vol. 6 (55) No. 1.

Dumova, E. (2011). Concepts of tourism development in the Irkutsk region for the period up to 2010, Economic strategies, No. 7, p. 54-86.

Filipushkova, A., Evdoshenko, O., Lyuceush A., Protasova, R. \& Chalikova, G. (2010). Traveling West of Baikal, Infomercial magazine, №1 (1), 150 p.

Funke, U. (1998). Methodological foundations of the development of urban concepts, Eurograde, No. 10. - p. 25-38.

Galazy, G.I. (2019). Lake Baikal, Encyclopedia Britanica, from https://www.britannica.com/place/Lake-Baikal, accessed 24.11.2019.

Galazy, G.I. (1987). Lake Baikal in Questions and Answers, Eastern-Siberian book publisher, 383 p.

Gozner, M., Josan, I., Baias, S. \& Măduta, F.M. (2016). The Religious Attractions - An Expression of Authenticity in the Territorial System Albac - Arieşeni and Alba County (Romania). GeoJournal of Tourism and Geosites, Year IX, Volume 1, Oradea-Gdansk, Romania-Poland, Editura Universităţii din Oradea.

Gozner, M., Tătar, C.F., Stupariu, M. \& Măduta, F.M. (2017). Nature, Photography and Tourism in BihorVlădeasa Mountains (Romania). GeoJournal of Tourism and Geosites, Year X, Volume 20, OradeaGdansk, Romania-Poland, Editura Universităţii din Oradea.

Ilies, D.C., Buhas, R., Ilies, M., Ilies, A., Gaceu, O., Pop, A.C., Marcu, F., Buhas, S.D., Gozner, M., \& Baias, S. (2018). Sport Activities and Leisure in Nature 2000 Protected Area - Red Valley, Romania. Journal of Environmental Protection and Ecology, 19, No 1, 367-372.

Ilieș, D. C., Oneț, A., Marcu, F.M., Gaceu, O.R., Timar, A., Baias, S., Ilieș, A., Herman, G.V. Costea, M., Țepelea, M., Josan, I. \& Wendt, J. (2018). Investigations regarding the air quality in the historic wooden church in Oradea city, Romania. Environmental Engineering and Management Journal, Vol.17, no11, pp.2731-2739, http://www.eemj.icpm.tuiasi.ro/pdfs/accepted/204_294_Ilie\%C8\%99_17.pdf.

Ilieş, D. C., Oneț, A., Wendt, J. Ilieş, M., Timar, A., Ilieș, A., Baias, S. \& Herman, G.V. (2018). Study on microbial and fungal contamination of air and wooden surfaces inside of a istorical Church from Romania. Journal of Environmental Biology, vol 39/6, pp.980-984, http://www.jeb.co.in/ journal_issues/ 201811_nov18/paper_06.pdf.

Indrie, L., Oana, D., Ilies, M., Ilies, D.C., Lincu, A., Ilies, A., Baias, S., Herman, G.V., Onet, A., Costea, M., Marcu, F., Burta, L. \& Oana, I. (2019). Calitatea aerului din interiorul muzeelor și conservarea operelor de artă din materiale textile. Studiu de caz: Casa-muzeu Sălacea, România/ Indoor air quality of museums and conservation of textiles art works. Case study: Salacea Museum House, Romania, 1/2019, pp. 88-93 http://www.revistaindustriatextila.ro/images/2019/1/Industria\%20textila\%20no\%201_2019_web.pdf. 
Kavaratzis, A. (2008). Place marketing: how did we get here and where are we going? Journal of Place Management and Development, Vol. 1 No. 2, pp. 150-165.

Kavaratzis, M. (2004). From city marketing to citybranding: Towards a theoretical frame-work for developingcity brands, Place Branding, Vol. 1, 1, pp. 58-73.

Komarov, A. E. (2005). The need to apply the concept of marketing to solving modern problems of closed cities, Actual problems of the development of the Russian economy, Novgorod: VGIPU, $56 \mathrm{p}$.

Kotler, F., Berger, R., \& Bickhoff, N. (2010). The Quintessence of Strategic Management: What You Really Need to Know to Survive in Business, Springer, $134 \mathrm{p}$.

Kotler, P., Asplund, C., Rein, I., \& Haider, D. (1999). Marketing Places Europe: How to Attract Investments, Industries, Residents and Visitors to Cities, Communities, Regions, and Nations in Europe, Financial Times.

Kotler, P., Gertner, D. (2002). Country as a Brand, Product and Beyond: A Place Marketing and Brand Management Perspective, Journal of Brand Management, Vol.9, No.4.

Lincu, A., Ilieș, M., Ilieș, D.C., Herman, G.V., Baias, S., Gozner, M., Costea, M., \& Mihincău, D. (2018). Conservating the traditional cellars of Salacea, Bihor County, Romania. GeoJournal of Tourism and Geosites, 23(3), 748-758, https://doi.org/10.30892/gtg.23311-325.

Lucarelli, A., Berg, P. O. (2011). City branding: a state-of-the-art review of the re-search domain, Journal of Place Management and Development, Vol. 4 Iss: 1, pp.9-27.

Lyubashevsky, Yu. (2005). Branding in Russia, Marketer, from http://www.marketolog.ru, accessed 22.02. 2012.

Niedomysl, J. (2012). Towards a theory of place marketing, Journal of Place Management and development. Vol. 5 No. 3, 2012, pp. 223-230.

Pankrukhin, A.P. (2008). Counter Marketing. Debranding and Destruction of the Image of the Territory, Corporate Imageology, No. 9. - p. 25-31.

Sanaev, B.G. (2011). The Development Strategy of the Far East and the Baikal Region, The Region: Economy and Strategy, 2, p.24.

Sevin, H. Efe (2014). Understanding cities through city brands: City branding as a social and semantic network, Cities 38, pp. 47-56.

Suprun, V. (2006). Images of Siberia, Expert Siberia, from. http://expert.ru/siberia/2006/27/imidzhi_sibiri, accessed 23.022012.

Szondi, G. (2007). The role and challenges of country branding in transition countries: The Central and Eastern European experience. Place Branding and Public Diplomacy, Vol. 3, p. 8-20.

Tătar, C.F., Herman, G.V. \& Gozner, M. (2018), Tourist Guides' ContributionTo Sustainability in Romania, GeoJournal of Tourism and Geosites, Year XI, no. 1, vol. 21, May 2018, p.282-287, Oradea-Gdansk, Romania-Poland, Editura Universităţii din Oradea; DOI 10.30892/gtg.21122-287, http://journals. indexcopernicus.com/karta.php?action $=$ masterlist\&id $=3947$

Terskikh, V. (2012). Image of Siberia in the aspect of branding of tourist destinations, Philosophy of Regions, from http://www.philology.ru/linguistics2/terskikh-11.htm, accessed 23.09.2012.

Vazhenina, I. S. (2008). Internet marketing of the image and reputation of the territory, Marketing in Russia and abroad, No. 7. - p. 25-32.

*** Freshwater Ecoregions of the World (2019). From http://www.feow.org/ecoregions/details/lake_baikal, accessed 23.09.2019.

*** Interfax Tourism (2019). "Rest in the + name of the region" from https://tourism.interfax.ru/ru/ news/articles/5344, accessed 23.09.2019.

*** Irk.ru. Tourism. News. (2019). The region's attractiveness, from http://www.bww.irk.ru/baikalinfo/ baikalnumbers.html, accessed 23.09.2019.

*** Lake Baikal, (2019). Wikipedia, from https://ru.wikipedia.org/wiki, accessed 24.11.2019.

*** Map of Lake Baikal (2019). From https://www.beautifulworld.com/asia/russia/lake-baikal/, accessed 24.11.2019.

*** Socio-political newspaper (2019) from http://www.ogirk.ru/2018/11/o7/v-irkutskoj-oblasti-poschitalituristov, accessed 23.09.2019.

Submitted:

07.09.2019
Revised:

11.12.2019
Accepted and published online 13.12.2019 